\title{
Postharvest Loss Control: Synergistic Plants Extract Inhibition of Ten Microbial Yam Rot Organisms
}

\author{
Dooshima Shiriki ${ }^{1}$, Godwin Oche Obochi' ${ }^{2}$, Mike Ojotu Eke ${ }^{3}$, Tseaa Shambe ${ }^{*}$ \\ ${ }^{1}$ Department of Biological Sciences, Benue State University, Makurdi, Nigeria \\ ${ }^{2}$ Department of Biochemistry, College of Health Sciences, Benue State University, Makurdi, Nigeria \\ ${ }^{3}$ Department of Food Science and Technology, University of Agriculture, Makurdi, Nigeria \\ ${ }^{4}$ Department of Chemistry, Benue State University, Makurdi, Nigeria \\ Email: ${ }^{\star}$ tshambe@bsum.edu.ng
}

How to cite this paper: Shiriki, D., Obochi, G.O., Eke, M.O. and Shambe, T. (2017) Postharvest Loss Control: Synergistic Plants Extract Inhibition of Ten Microbial Yam Rot Organisms. Food and Nutrition Sciences, 8, 725-732.

https://doi.org/10.4236/fns.2017.87051

Received: June 6, 2017

Accepted: July 10, 2017

Published: July 13, 2017

Copyright (๑) 2017 by authors and Scientific Research Publishing Inc. This work is licensed under the Creative Commons Attribution International License (CC BY 4.0).

http://creativecommons.org/licenses/by/4.0/

\begin{abstract}
Nine microorganisms were isolated from four varieties of Dioscorea rotundata (gbongu, ogoja, Amula, Hembamkwase); four bacteria, Erwinia carotovora, Pseudomonas aeruginosa, Serratia marcescens, Klebsiella oxytoca and five fungi, Rhizopus stolonifera, Aspergillus niger, Aspergillus flavus, Fusarium oxysporum, Penicillium marneffei, from five local government areas of Benue State (Vandeikya, Ukum, Katsina Ala, Guma and Logo). Pathogenicity test on the isolates confirmed them to be the cause of rot. The nine plants extract (Ceiba pentandra, Jatropha tanjorensis, Azadirachta indica, Moringa oleifera, Carica papaya, Mangifera indica, Daniella oliveri, Terminalia catapa and Passiflora edulis) synergistically added inhibited all the four bacteria isolates completely. The five fungi were inhibited by $60 \%$ (c) - $80 \%$ (b); Rhizopus stoIonifera, Aspergillus flavus, Fusarium oxysporum; and Aspergillus niger, Penicillium marneffei, respectively.
\end{abstract}

\section{Keywords}

Plant Extracts, Synergistic, Microorganisms, Inhibition, Yam Rot

\section{Introduction}

Africa is the highest producer of yam in the world. West Africa is the largest producer of yam in Africa and Nigeria, the highest in West Africa [1] [2] [3]. Benue state in the north central zone of Nigeria is the leading producer or at least among the leading producers of yam in the world. This is because of its fa- 
vorable climatic condition like whether as well as soil [4] [5] [6]; unfortunately it is plague with postharvest losses. Postharvest losses are caused by high temperature, sprouting, nematodes, rodents, insects and microorganisms. The most devastating is that caused by microorganism [5]. Our earlier studies as well as other researchers show that bacteria and fungi are responsible for the highest losses [5] [6] [7] [8]. Research has shown that these loss causing organisms exist in an associative growth with each organism causing its characteristic damage which is evident in tissue damage and coloration [7] [8].

Pesticides and plant extracts can be used to prevent or at least reduce postharvest losses in yam [9] [10] [11]. Crops treated with pesticides have longer shelf life and prevent infestation by insects and microorganisms; unfortunately pesticides are also plague with toxicity, resistance of micro-organisms, environmental pollution and health hazards to users as lack of cleanliness may generate ill health; as a result, the crops treated with pesticides are not readily accepted in the international markets [12]. Unlike pesticides, no serious report has been recorded against Microbial resistance to plant extract [13].

Plant extracts are known to inhibit partially or completely only selected organisms [7] [8] [11]. Most single plant extracts are often unable to partially or completely inhibit all isolates [11]. Synergistic effect of some plants recorded better inhibition of $60 \%$ to $80 \%$ on some micro-organisms [9]. This is in agreement with what most African countries and perhaps other nations were using for their health care [13].

The aim of this work is to use plants which are known to be food to mankind and are at the same time used for medicinal purposes for humans and livestock, for preservation of food and indeed control of postharvest losses. It is hoped that with careful blending and changes in concentration of extracts applied to the organisms, complete or higher percentage of inhibition of all microorganisms may be achieved. This study reports our findings on synergistic effects using nine plants (Ceiba pentandra, Jatropha tanjorensis, Azadarichta indica, Moringa oleifera, Carica papaya, Mangifera indica, Daniella oliveri, Terminalia catapa and Passiflora edulis) and nine microorganisms; four bacteria (Erwinia carotovora, Pseudomonas aeruginosa, Serratia marcescens, Klebsiella oxytoca) and five fungi (Rhizopus stolonifera, Aspergillus niger, Aspergillus flavus, fusarium oxysporum, Penicillium marneffei).

\section{Materials and Methods}

\subsection{Source of Materials}

Sixty cut or bruised tubers and sixty healthy tubers of Discorea rotundata; 6 tubers of each of the varaieties (Gbongu, Ogoja, Amula and Hembamkwase) were purchased from farmers in Vandeikya, Ukum, Katsina Ala, Guma and Logo Local government area of Benue State, amounting to 15 tubers of each variety per local government. The samples were labeled, dated, and packaged in cellophane bags at collection sites. These were transported to the Microbiology Laboratory 
of Benue State University, Makurdi; where they were kept and some were analyzed on appearance of visible sign of rot, while others were used for pathogenicity test.

Plant leaves of Ceiba pentandra, Jatropha tanjorensis, Azadarichta indica, Moringa Oleifera, Carica papaya, Mangifera indica, Daniella oliveri, Terminalia catapa and Passiflora edulis used for the plants extract were collected along Gboko road, Makurdi.

\subsection{Isolation of Microorganisms}

Isolation of bacteria and fungi from rotten yam tubers was carried out by the methods of [7] [11].

\subsubsection{Sample Preparation}

The methods of [7] [11] were used without any modifications. The samples were individually washed in clean water to remove surface dirt and air dried. The skin was cut open to reveal the rotten tissues and about $5 \mathrm{~mm}$ pieces of the tissues were then cut into a beaker. A 10\% sodium hypochlorite solution was added and held for 2 minutes. This was drained and washed three times with sterile water. They were then dried in a laminar air flow cabinet for 5 minutes on Whatman No.1 filter paper.

\subsubsection{Culture Media Preparation}

Nutrient Agar (HIMEDIA, India) for bacteria isolation and potato dextrose agar (Micro Master, India) for fungi isolation were prepared according to manufactures directions respectively. Biochemical test media and reagent were also prepared according to standard methods [7].

\subsubsection{Direct Seeding}

The method of [7] was used without any modification. The prepared pieces of yam samples were seeded, 3 pieces each, onto the prepared nutrient agar and potato dextrose agar plates respectively, incubated for 48 hours for the bacteria and seven days for the fungi.

\subsubsection{Isolates Identification}

The distinct colonies of organisms were sub-cultured severally until a single uniform growth was achieved. The bacteria were identified by the method of [14] and the fungi by the method of [15] [16].

\subsubsection{Test for Pathogenicity}

The methods of [7] [11] were used with little modifications; the isolates were tested to establish that tuber rot was due to their growth and activity in the tissues. The healthy yam tubers were washed in running tap water to remove surface dirt and soil. They were allowed to air dry, then their surfaces sterilized by cleaning with $70 \%$ ethanol solution. The outer layer was cut at a portion of the yam (but not allowed to fall off), $5 \mathrm{~mm}$ deep hole was made into the exposed tissues using a sterile $5 \mathrm{~mm}$ cork borer. A $3 \mathrm{~mm}$ cork borer was used to lift the 
organisms and placed in the hole made for each category. The skin was replaced and sealed with a masking tape. This was kept in a safe chamber and monitored for nine days. Tubers were cut open transversely, tissue damage and pigmentation were compared with the initial parent rot, width and depth of rot was measured. Re-isolation of the seeded organisms was carried out. The test was carried out in triplicate and average measurement of width and depth of rot were recorded.

\subsubsection{Plants Extract Preparation.}

The methods of the Tiv traditional health care in Benue, Nigeria, using plant extracts (unpublished work) and [17] [18] were used with little modifications; plant leaves were blended in a ratio of 1:1. This forms the nucleus of the work. Fresh leaves of nine plants (Ceiba pentandra, Jatropha tanjorensis, Azadarichta indica, Moringa Oleifera, Carica papaya, Mangifera indica, Daniella oliveri, Terminalia catapa and Passiflora edulis) were collected, washed in clean water, put to drain in a clean plastic basket for 10 minutes. They were weighed $(20.0 \mathrm{~g}$ each) using an electronic digital weighing balance (OHAUS model Scout pro SPU601). The leaves were cut to fine shredding with a kitchen knife and blended using a warring blender (Okapi, Marshall) into fine paste. The mix (50.0 g) was weighed into a sterilized $500 \mathrm{~mL}$ conical flask, $200 \mathrm{~mL}$ of sterile water was added and stirred with a magnetic stirrer for 10 minutes (Stuart, SB 162), it was plugged with cotton wool and kept to extract for 12 hours at room temperature. This was filtered with Whatman No 1 filter paper, the residue was washed with $10 \mathrm{~mL}$ of water four times. The combined volume was centrifuge (Centurion 2000 series) at $3500 \mathrm{rpm}$ for 3 minutes. The supernatant was decanted into a sterile bottle, properly corked and stored in the refrigerator for antimicrobial inhibition test.

\subsubsection{Plant Extract Incorporation}

The method of [11] was used. The extract, $1.0 \mathrm{~mL}-5.0 \mathrm{~mL}$, each were pipette into sterile petri dishes and $20 \mathrm{~mL}$ of molten agar or potato dextrose agar held at $45^{\circ} \mathrm{C}$ was poured on it respectively and mixed thoroughly. These were allowed to solidify and used for the inhibition test.

\subsubsection{Inhibition Test}

The methods of [7] [11] were used with little modifications; the bacteria and fungi isolates were seeded individually on the plants extract incorporated nutrient agar and potato dextrose agar respectively, controls were also set up by seeding on media without extract addition and incubated at $37^{\circ} \mathrm{C}$ for 48 hours for the bacteria and 7days for the fungi; using the optimum temperature obtained from earlier work [7] [8]. Various concentrations of the extract in the media was used by adding $1.0 \mathrm{~mL}$ to $5.0 \mathrm{~mL}$ to observe the effect of changes in concentration of the synergistic mixture on the microorganisms. The plates were observed for microbial activity. Growth diameter was measured and compared with the control to device a percentage growth width using a transparent plastic 
ruler.

\section{Results and Discussion}

\subsection{Results}

Four bacteria species (Erwinia carotovora, Pseudomonas aeruginosa, Serratia marcescens and Klebsiella oxytoca) and five fungi species (Rhizopus stolonifera, Aspergillus niger, Aspergillus flavus, Fusarium oxysporum and Penicillium marneffei were isolated from the rotten yam tubers (Table 1).

Pathogenicity test on the isolated microorganisms showed tissue rot, damage intensity and different pigment production by different microorganisms. Reisolation of the seeded organisms from the rotten tissues confirms them to be responsible for the rot (Table 2).

Synergistic effect of nine plants extract mix on the isolates reveals that $1.0 \mathrm{~mL}$ addition of extracts in the culture media was able to inhibit mildly (e) the growth

Table 1. Microorganisms Isolated from Rotten Dioscorea rotundata (White Yams).

\begin{tabular}{cc}
\hline Bacteria & Fungi \\
\hline Erwinia carotovora & Rhizopus stolonifera \\
Pseudomonas aeruginosa & Aspergillus niger \\
Serratia marcecens & Aspergillus flavus \\
Klebsiella oxytoca & Fusarium oxysporum \\
& Penicillium marneffei \\
\hline
\end{tabular}

Table 2. Pathogenicity Test/Average Triplicate Rot Measurements $(\mathrm{cm})$ of Yam Tuber Varieties.

\begin{tabular}{ccccccccc}
\hline \multirow{2}{*}{ Microorganisms } & \multicolumn{8}{c}{ Yam Varieties } \\
\cline { 2 - 9 } & Width & depth & Width & depth & Width & depth & Width & depth \\
\hline $\begin{array}{c}\text { Erwinia carotovora } \\
\text { Psendomona }\end{array}$ & 1.2 & 2.3 & 1.2 & 2.9 & 1.0 & 4.8 & 1.8 & 3.2 \\
$\begin{array}{c}\text { aeruginosa } \\
\text { Serratia marcescens }\end{array}$ & 2.1 & 3.0 & 1.4 & 2.9 & 1.2 & 2.4 & 1.5 & 3.0 \\
Klebsiella oxytoca & 1.2 & 3.1 & 1.2 & 3.0 & 1.1 & 2.2 & 1.2 & 3.2 \\
Rhizopus stolonifera & 2.3 & 1.8 & 1.5 & 2.8 & 1.4 & 3.6 & 1.6 & 2.4 \\
Aspergillus niger & 1.7 & 3.1 & 1.0 & 2.6 & 1.0 & 2.6 & 1.0 & 2.8 \\
Aspergillus flavus & 1.8 & 2.6 & 2.1 & 3.2 & 1.8 & 2.4 & 2.3 & 3.2 \\
Fusarium oxysporum & 2.1 & 2.2 & 1.2 & 2.4 & 1.6 & 3.0 & 1.0 & 2.0 \\
$\begin{array}{c}\text { Penicillium maneffei } \\
\text { All bacteria }\end{array}$ & 1.2 & 2.0 & 1.5 & 2.2 & 1.1 & 2.0 & 1.6 & 2.4 \\
All fungi & 2.1 & 3.6 & 2.2 & 3.4 & 1.6 & 3.2 & 2.0 & 3.4 \\
All bacteria and all & 2.0 & 3.3 & 2.7 & 3.3 & 1.8 & 2.2 & 2.2 & 3.6 \\
fungi & 3.1 & 3.5 & 2.3 & 3.6 & 2.4 & 4.2 & 3.6 & 4.2 \\
\hline
\end{tabular}


of only two bacteria (Erwinia carotovora and Klebsiella oxytoca) without affecting the other bacteria or fungi; $2.0 \mathrm{~mL}$ incorporation of the extract was able to inhibit all the four bacteria isolates completely, the fungi isolates were still not inhibited. Addition of $3.0 \mathrm{~mL}$ of extract showed mild inhibition (e) for Aspergillus niger and Penicillium marneffei without affecting the other three fungi; 4.0 $\mathrm{mL}$ incorporation of the extract showed mild inhibition (e) of Rhizopus stolonifera and Fusarium oxytoca, moderate inhibition (d) of Aspergillius niger, Penicillium marneffei and Aspergillus flavus. There was marked increase in the inhibition with the addition of $5.0 \mathrm{~mL}$ of the extract, showing good inhibition (c) for Rhizopus stolonifera, Aspergillus flavus and Fusarium oxysporum; and high inhibition (b) for Aspergillus niger and Penicillium marneffei (Table 3).

\subsection{Discussion}

The study confirms the isolate as microorganisms responsible for microbial yam tuber losses in most part of Benue State, Nigeria as they were previously isolated [7] [8]. The isolation of Aspergillus flavus and absence of Botryodiplodia theobromae from rotten Dioscorea rotundata in the present work as against the previous work [7] is an indication that presence of the organisms varies with daily climatic changes.

Pathogenicity test confirms that the isolates were responsible for the yam tuber rot as earlier reported [7] [8] and indeed in agreement with other reports [4] [8].

The complete inhibition of the four bacteria (Erwinia carotovora, Pseudomonas aeruginosa, Serratia marcescens and Klebsiella oxytoca) by the synergistic plants extract (Ceiba pentandra, Jatropha tanjorensis, Azadarichta indica, Moringa Oleifera, Carica papaya, Mangifera indica, Daniella oliveri, Terminalia catapa and Passiflora edulis) has not yet been reported by other workers, using

Table 3. Synergistic Activity of Plant Extracts Incorporation on Isolates.

\begin{tabular}{|c|c|c|c|c|c|}
\hline \multirow[t]{2}{*}{ Microorganism } & \multicolumn{5}{|c|}{ Extract volume applied } \\
\hline & $1 \mathrm{ml}$ & $2 \mathrm{ml}$ & $3 \mathrm{ml}$ & $4 \mathrm{ml}$ & $5 \mathrm{ml}$ \\
\hline \multicolumn{6}{|l|}{ Bacteria } \\
\hline Erwinia carotovora & + & $+++++^{\mathrm{a}}$ & NA & NA & NA \\
\hline Pseudomonas aeruginosa & $-{ }^{f}$ & $+++++^{\mathrm{a}}$ & NA & NA & NA \\
\hline Serratia marcescens & $-f$ & $+++++^{\mathrm{a}}$ & NA & NA & NA \\
\hline Klebsiella oxytoca & $+{ }^{e}$ & $+++++^{\mathrm{a}}$ & NA & NA & NA \\
\hline \multicolumn{6}{|l|}{ Fungi } \\
\hline Rhizopus stolonifera & $-^{\mathrm{f}}$ & $-{ }^{\mathrm{f}}$ & $-{ }^{\mathrm{f}}$ & $+^{\mathrm{e}}$ & $+++^{c}$ \\
\hline Aspergillus niger & $--^{\mathrm{f}}$ & $-^{\mathrm{f}}$ & $+^{e}$ & $++^{\mathrm{d}}$ & $++++^{\mathrm{b}}$ \\
\hline Aspergillus flavus & $-{ }^{\mathrm{f}}$ & $-{ }^{f}$ & $-{ }^{f}$ & $++^{\mathrm{d}}$ & $+++^{\mathrm{c}}$ \\
\hline Fusarium oxysporum & $-{ }^{\mathrm{f}}$ & $--^{f}$ & $-^{\mathrm{f}}$ & $+^{e}$ & $+++^{c}$ \\
\hline Penicillium marneffei & $-{ }^{\mathrm{f}}$ & $-^{\mathrm{f}}$ & $+^{\mathrm{e}}$ & $++^{\mathrm{d}}$ & $++++^{\mathrm{b}}$ \\
\hline
\end{tabular}


synergistic or single plant extracts. Single bacteria have been inhibited by synergistic plant extracts as well as single plant extract [7] [8] [11]. In earlier work [7] [8], it was only Erwinia carotovora, that was inhibited completely (a), by a single plant extract (Terminelia catapa); Pseudomonas aeruginosa and Klebsiella oxytoca recorded good inhibition (b) with Jatropha tanjorensis plant extract. Synergistic extract appear to enhance the complete inhibition of bacteria more than the fungi. The synergistic mixture comprising of plants earlier used was not able to inhibit completely Rhizopus stolonifera earlier completely inhibited (a) by single plant extract, Passiflora edulis [8]; most probably because the concentration of the individual plants in the synergistic mixture was not sufficient to give complete inhibition; more so that inhibition increases with increase in concentration of the plant extract. All the fungi studied showed lower inhibition with synergistic extract compared with single extract and showed a gradual increase in inhibition with increase in concentration of the synergistic extract. The result is in agreement with the findings of [19]. Fungi spore formation time delayed on $5.0 \mathrm{~mL}$ extract media from 3 days to 7 days in the isolates, which suggest most strongly that higher concentrations shall be more effective and may inhibit it completely.

\section{Conclusion}

The plants in the study are all edible by man and livestock without any recorded danger on health. There is need to research further on the use of synergistic plants extract for their application on tubers and perhaps crops in general to prevent microbial rot and poison for shelf life elongation and the economic benefits that may follow.

\section{Acknowledgements}

Our gratitude goes to the management of Benue State University Makurdi for the facilities and finances made available to us to carry out this research, the famers in the various local governments where the samples were obtained. We appreciate the assistance of the staff of Biology and Chemistry Departments of Benue State University.

\section{References}

[1] Glover, A.M., Quansah, J. and Peget, F.M. (2013) Performance and Acceptability of Legume-Fortified Yam Flours. Food Science and Quality Management, 17, ISSN 2225-0557 (Online).

[2] Anjori, T.B., Nwokocha, O.V. and Sanni, A.D. (2014) Morphological Characteristics and Incidence of Diseases on White Yam (Dioscorea rotundata L. Poir) Tubers in Abuja Nigeria. Nature and Science, 12, No. 7. http://www.sciencepub.net/nature

[3] Osunde, Z.D. (2008) Minimizing Postharvest Losses in Yam (Dioscorea spp.): Treatment and Techniques. International Union of Food Science and Technology, Raleigh, 1-12.

[4] Akangbe, J.A., Oloruntoba, O.O., Ayanda, I.F. and Komolafe, S.E. (2012) An Analysis of Yam Storage Strategy to Promote Food Security in Asa Local Government 
Area of Kwara State, Nigeria. Ethiopian Journal of Environmental Studies and Management, 5. https://doi.org/10.4314/ejesm.v5i4.S15

[5] Ajayi, A.O. and Olorundare, S.D. (2014) Bacterial and Fungal Species Associated with Yam (Dioscorea rotundata) Rot at Akanugba-Akoko, Ondo Staste, Nigeria. Applied Science Research Journal, 2, 12-28.

[6] Taiga, A. (2012) Differential Rate of Dry Rot in Dioscorea rotundata (White Yam) along the Tuber Length due to Rot Causing Fungi. Advances in Microbiology, 2, 452-455. https://doi.org/10.4236/aim.2012.24058

[7] Shiriki, D., Ubwa, S.T. and Shambe, T. (2015) Isolation of Nine Microorganisms from Rotten Dioscrea rotundata (White Yam) and Antimicrobial Sensitivity Test with Five Plant Extracts. Food and Nutrition Sciences, 6, 825-835.

https://doi.org/10.4236/fns.2015.610086

[8] Onuh, J.O., Shiriki, D., Ubwa, S.T. and Shambe, T. (2015) Isolation of Six Microorganisms from Rotten Dioscorea alata (Water Yam), and Antimicrobial Sensitivity Test with Nine Plant Extracts. Food and Nutrition Sciences, 6, 1381-1394. https://doi.org/10.4236/fns.2015.615144

[9] Anjum Malik, A., Ahmed, N., Babita, Chauhan, H. and Gupta, P. (2016) Plant Extracts in Post-Harvest Disease Management of Fruits and Vegetables: A Review. Journal of Food Processing \& Technology, 7, 592. https://doi.org/10.4172/2157-7110.1000592

[10] Deshi, S.N., Wonang, D.L. and Dafur, B.S. (2014) Control of Rots and Spoilage of Agricultural Products: A Review. Academic Journal of Interdisciplinary Studies, 3, No. 7. https://doi.org/10.5901/ajis.2014.v3n7p38

[11] Okigbo, R.N., Agbata, C.A. and Echezona, C.E. (2010) Effects of Leaf Extracts of Azadirachta indica and Chromolaena odorata on Post Harvest Spoilage of Yams in Storage. Current Research Journal of Biological Sciences, 2, 9-12.

[12] Ijato, J.Y. (2011) Evaluation of Antifungal Effects of Extracts of Allium sativum and Nicotiana tobacum against Soft rot of Yam (Dioscorea alata). Researcher, 3, 1-5. http://www.sciencepub.net

[13] Asare, P. and Oseni, L.A. (2012) Comparative Evaluation of Ceiba pentandra Ethanolic Leaf Extract, Stem Bark and the Combination Thereof for In-Vitro Bacterial Growth Inhibition. Journal of Natural Sciences Research, 2, 44-49. www.iiste.org

[14] Krieg, N. (1984) Bergeys Manual of Systematic Bacteriology. Vol. 1, Williams and Wilkins, Baltimore, 21-38.

[15] Barnett, H.L. and Hunter, B.B. (1972) Illustrated General of Imperfect Fungi. 3rd Edition, Burgess Publications Co., Minneapolis, 241.

[16] Sutton, B.C. (1980) The Coelomycetes Fungi Imperfecti with Pycenidia, Acervuli and Stromata. Commonwealth Mycological Institute, Kew, Surrey, England, 696.

[17] Banso, A. and Sani, A. (2003) Antibacterial Effect of Leaf Etract of Ricinus communis. African Scientist, 4, 129-133. http://Klobexpublishers.com

[18] Orhue, P.O., Momoh, A.R.M., Igumbor, E.O. and Esumeh, F.I. (2014) Antibacterial Effect of Azadirachta indica (CN: Neem or Dongo Yaro) Parts on Some Urinary Tract Bacterial Isolates. Asian Journal of Plant Science and Research, 4, 64-67.

[19] Nascimento, G.G.F., Locatelli, J., Freitas, P.C. and Silva, G.L. (2000) Antibacterial Activity of Plant Extracts and Phytochemicals on Antibiotic-Resistant Bacteria. Brazilian Journal of Microbiology, 31. https://doi.org/10.1590/S1517-83822000000400003 
Submit or recommend next manuscript to SCIRP and we will provide best service for you:

Accepting pre-submission inquiries through Email, Facebook, LinkedIn, Twitter, etc. A wide selection of journals (inclusive of 9 subjects, more than 200 journals)

Providing 24-hour high-quality service

User-friendly online submission system

Fair and swift peer-review system

Efficient typesetting and proofreading procedure

Display of the result of downloads and visits, as well as the number of cited articles Maximum dissemination of your research work

Submit your manuscript at: http://papersubmission.scirp.org/

Or contact fns@scirp.org 